\title{
PENGEMBANGAN APLIKASI STATISTIKA BERBASIS ANDROID UNTUK ANALISIS UJI-T DUA SAMPEL INDEPENDEN
}

\author{
Hindayati Mustafidah ${ }^{1}$, Fadhilah Ramadhan ${ }^{2}$ \\ 1,2Teknik Informatika, Universitas Muhammadiyah Purwokerto
}

Email korespondensi:h.mustafidah@ump.ac.id

\begin{abstract}
Abstrak
Keakuratan data menjadi sesuatu yang sangat penting dalam berbagai segi kehidupan, terutama bagi kalangan akademisi maupun praktisi. Data diolah untuk dijadikan sebagai sumber informasi. Cara atau metode pengolahan data banyak dikenal dengan sebutan metode statistika. Di kalangan akademisi, telah banyak dikenal program komputer untuk pengolahan data statistik, di antaranya adalah SPSS dan R untuk mengolah data penelitian yang dilakukan. Alat penghitung dan pengolah data yang efisien menjadi kebutuhan utama bagi peneliti guna memperoleh hasil analisis yang tepat dan cepat terutama dalam penarikan kesimpulan. Oleh karena itu, penelitian ini mengembangkan sebuah aplikasi analisis statistik berbasis android untuk menganalisis data menggunakan uji-t 2 sampel independen. Aplikasi ini dibangun menggunakan alur model waterfall. Penelitian ini menghasilkan sebuah aplikasi statistika yang dapat mengolah data dengan kemampuannya memberikan sebuah kesimpulan berbentuk deskripsi kalimat berdasarkan hipotesis yang ditentukan. Dengan demikian, pengguna tidak perlu lagi menafsirkan sendiri hasil analisis data yang dilakukan. Hal ini sangat membantu pengguna dalam menyimpulkan atas kondisi data yang diolah tanpa melakukan interpretasi hasil analisis datanya, sehingga dapat mempercepat pekerjaan olah data dan terhindar dari kesalahan pemaknaan terhadap hasil analisis data.
\end{abstract}

10.26418/pipt.2021.28

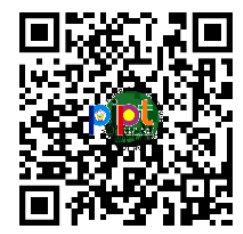

Kata kunci: analisis data, uji-t 2 sampel independen, aplikasi statistika, android.

\section{PENDAHULUAN}

Keakuratan data merupakan hal yang sangat penting untuk semua bidang, terutama bagi kalangan akademisi maupun praktisi. Data yang akurat dapat diperoleh jika analisisnya menggunakan metode yang tepat, yaitu metode statistika. Di kalangan akademisi, banyak dikenal adanya program aplikasi untuk pengolahan data statistik, di antaranya adalah SPSS dan $\mathrm{R}$ untuk menunjang kegiatan penelitiannya. Pemanfaatan teknologi aplikasi olah data dan analisis uji statistik yang sudah ada dan populer adalah aplikasi SPSS (Machali, 2015).

Statistical Package for Social Science atau yang dikenal dengan SPSS, merupakan paket statistika yang pada awalnya diperuntukkan bagi pengolahan data dalam ilmu sosial (Taniredja \& Mustafidah, 2011). Namun seiring dengan berkembangnya ilmu, SPSS banyak juga digunakan sebagai alat bantu analisis data di bidang lain. SPSS menjadikan output sebagai kesimpulan dari hasil perhitungan yang diproses dari aplikasi, namun dari hasil analisis yang diperoleh tersebut, pengguna aplikasi masih belum bisa melihat hasil kesimpulan apakah hipotesis $\mathrm{H}_{0}$ diterima ataupun ditolak. Oleh karena itu pengguna aplikasi perlu melihat data output dan melakukan interpretasi secara manual. Untuk menganalisis data, diperlukan identifikasi aturan pengukuran yang disebut skala pengukuran (Ary, 2016). Terkait dengan penetapan hipotesis dalam sebuah penelitian, hipotesis nol pada perbedaan dalam mean adalah nol, yaitu, $\mathrm{H}_{0}: \mu 1=\mu 2$ atau, $\mathrm{H}_{0}: \mu 1-\mu 2=0$. Dalam kebanyakan kasus, hipotesis alternatifnya adalah bahwa mean tidak sama, yaitu, Ha: $\mu 1 \neq \mu 2$ (Gauthier \& Mark E, 2017).

Seorang peneliti yang menggunakan alat bantu untuk analisis data, sangat membutuhkan alat bantu hitung dan analisis yang efisien agar penelitiannya memperoleh hasil yang tepat dan mudah dipahami, yaitu pendeskripsian dalam bentuk kalimat. Kebutuhan ini sangat mendasar karena diperlukan pada saat penarikan sebuah 
kesimpulan. Berdasarkan hal tersebut, penelitian ini bertujuan untuk membangun sebuah aplikasi statistika berbasis android khususnya untuk analisis uji-t dua sampel independen. Aplikasi ini dikembangkan berbasis android dengan tujuan untuk memudahkan pengguna agar bisa mengakses kapanpun dan di manapun, karena mayoritas masyarakat menggunakan perangkat seluler dengan sistem operasi android. Menurut data statistik yang dilaporkan oleh eMarketer, pada tahun 2019 pengguna smartphone di Indonesia ada di angka 92 juta, seperti yang ditunjukkan pada Gambar 1 (eMakerter, 2019). Alasan pemilihan basis Android sebagai dasar pengembangan aplikasi adalah karena di samping lebih mudah dalam pengoperasiannya, juga memiliki sifat mobile yang fleksibel.

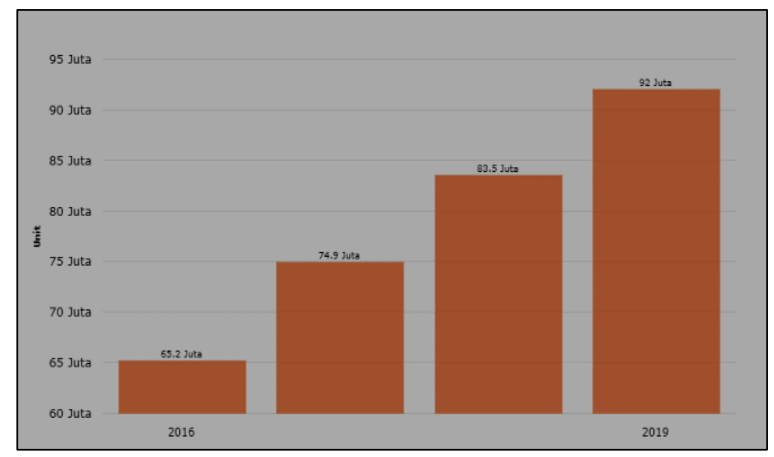

Sumber: (eMakerter, 2019)

Gambar 1: Jumlah pengguna smartphone di Indonesia

Jenis analisis uji-t adalah yang paling banyak digunakan selain Chi-Kuadrat (Pandey, 2015). Beberapa penelitian yang menggunakan uji-t dalam analisis datanya adalah yang dilakukan oleh (Wanakacha et al., 2018), (Yusop et al., 2015), dan (Sagoro, 2016). Aplikasi statisti-k yang dikembangkan ini ditujukan untuk analisis data yang pada uji-t 2 sampel independen. Uji-t diterapkan untuk menguji signifikansi rata-rata sampel acak dan perbedaan antara rata-rata dua sampel (Gerald, 2018). Selain aplikasi ini dapat memberikan hasil perhitungan secara terperinci, cepat, dan tepat, fokus utamanya adalah dapat menghasilkan sebuah kesimpulan berupa kalimat atau deskripsi terhadap penerimaan atau penolakan Ho.

\section{METODOLOGI}

Penelitian ini menggunakan pendekatan kualitatif dengan jenis penelitian pengembangan (Mustafidah \& Suwarsito, 2020) yaitu mengembangkan sebuah aplikasi untuk menganalisis data menggunakan uji-t pada 2 sampel independen. Aplikasi dikembangkan menggunakan model waterfall yang melalui tahapan yaitu analisis kebutuhan, desain, pengkodean, pengujian, dan implementasi (Rosa \& Shalahuddin, 2014). Tahapan dalam model ini diilustrasikan seperti pada Gambar 2.

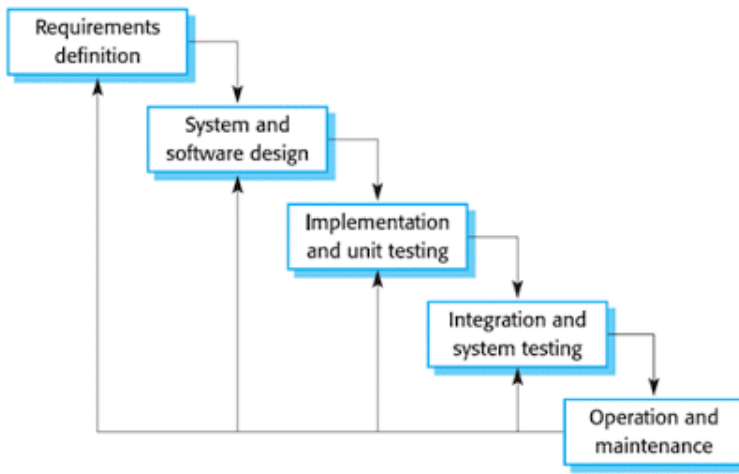

Sumber: (Rosa \& Shalahuddin, 2014)

Gambar 2: Model pengembangan Waterfall

Sebagaimana pada Gambar 2, tahap awal dalam model waterfall adalah analisis kebutuhan yang meliputi kebutuhan perangkat untuk mengembangkan aplikasi maupun kebutuhan data. Selain perangkat keras komputer, software yang dibutuhkan dalam penelitian ini adalah Java, Android Oreo 8.0, DB Browser for SQLite, Android Studio, dan SPSS. Sementara itu kebutuhan data yang diolah dalam aplikasi diperoleh dengan cara dokumentasi dari buku Machali (2015). Selanjutnya sistem didesain menggunakan flowchart sebagaimana tersaji pada Gambar 3. 


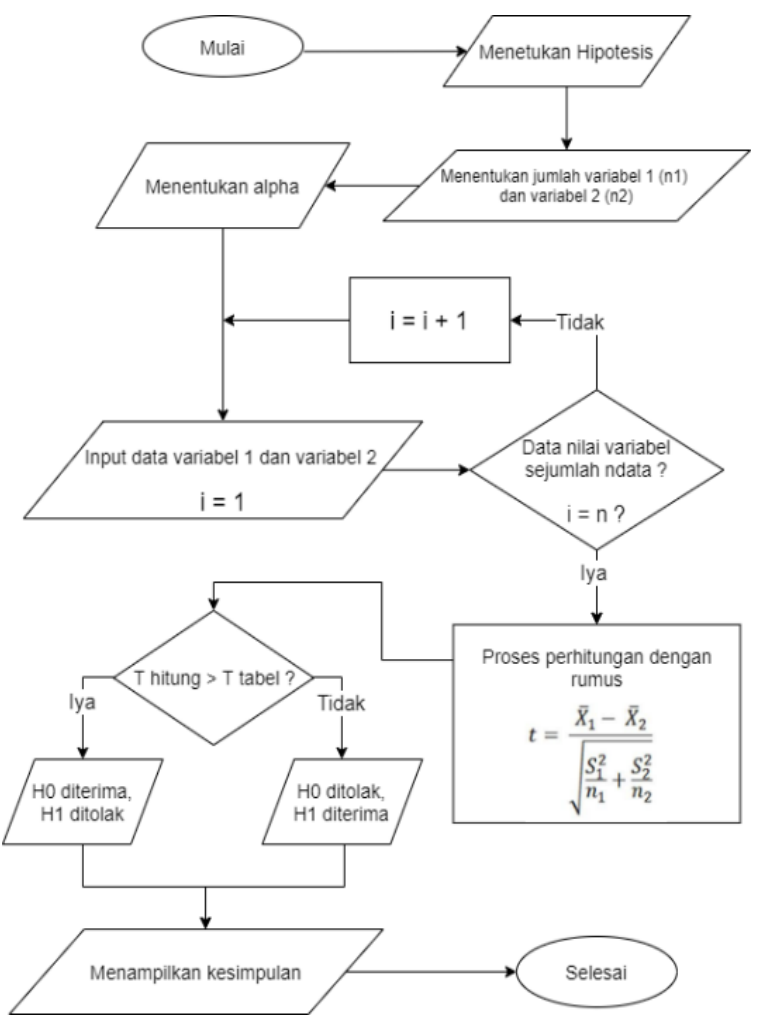

Sumber: (Penulis, 2021)

Gambar 3: Flowchart pengembangan aplikasi analisis data uji-t 2 sampel independen

Flowchart pada Gambar 3 menjelaskan tentang proses perhitungan pada analisis data menggunakan uji-t, di mana proses yang pertama adalah menentukan hipotesis, menentukan jumlah data pada variabel 1 (n1) dan variabel 2 (n2), alpha, input data pada variabel 1 dan variabel 2 . Kemudian data tersebut diproses menggunakan rumus $T_{\text {hitung. }}$. Berdasarkan hasil dari $T_{\text {hitung }}$ selanjutnya dibandingkan dengan nilai $T_{\text {tabel }}$ untuk menghasilkan sebuah kesimpulan.

Tahap selanjutnya yaitu implementasi, di mana keseluruhan desain aplikasi yang telah disusun sebelumnya diubah menjadi kodekode program dengan menggunakan bahasa pemrograman Java dan modul-modul yang diintegrasikan menjadi sebuah aplikasi. Tahapan berikutnya yaitu integrasi dan pengujian fungsionalitas terhadap aplikasi yang dikembangkan. Sementara itu, tahapan terakhir yaitu proses pemeliharaan aplikasi mulai dari perbaikan-perbaikan dari kesalahan kode ataupun bug yang tidak ditemukan oleh tahap testing.

\section{HASIL DAN PEMBAHASAN}

\section{Implementasi Sistem}

\section{Halaman Utama}

Halaman utama adalah antar muka yang tampak pertama pada saat pengguna menjalankan aplikasi (Gambar 4). Pada halaman utama ini terdapat teks "Aplikasi statistik analisis data menggunakan Uji T 2 sampel independen", yang bertujuan sebagai informasi bahwa aplikasi ini hanya digunakan untuk analisis data menggunakan Uji-t 2 sampel independen. Halaman utama ini memiliki 4 menu yaitu menu Data Anda, menu Analisis Data, menu Panduan, dan menu About.

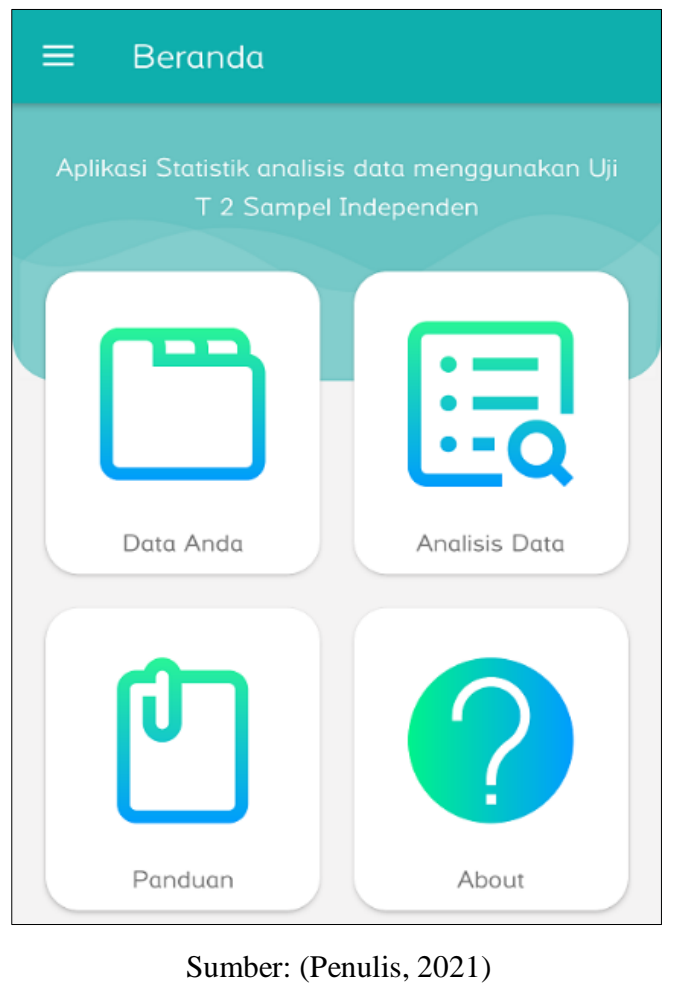

Gambar 4: Tampilan halaman utama

\section{Halaman Data Anda}

Halaman Data Anda menampilkan data hasil analisis pengguna aplikasi. Halaman ini digunakan sebagai riwayat analisis data yang bisa dilihat kembali maupun diubah (Gambar $5)$. 


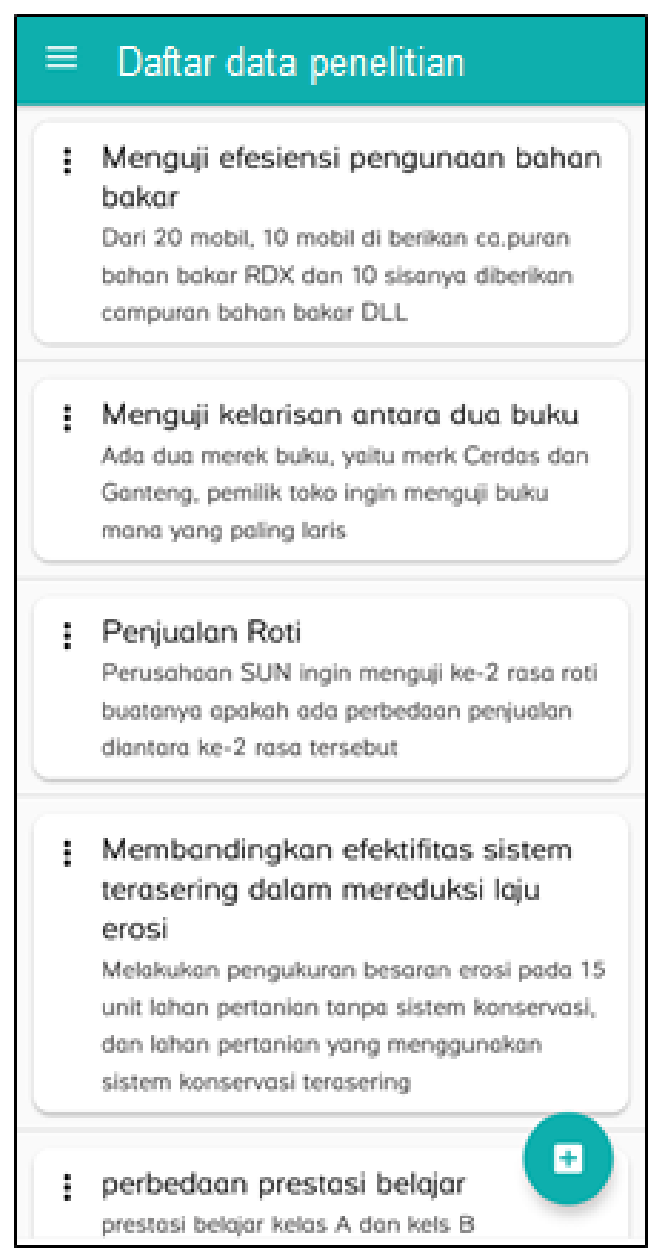

Sumber: (Penulis, 2021)

Gambar 5: Tampilan halaman "Data Anda"

Pada halaman ini terdapat tombol $\mathbf{\vdots}$ yang bisa digunakan untuk mengubah, menghapus, melihat detail data, Report data, dan Export data, seperti pada Gambar 6.

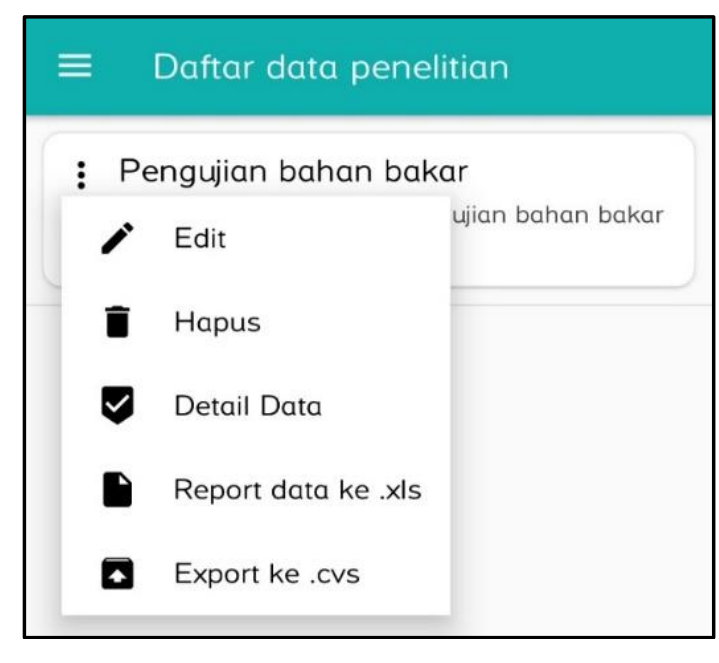

Sumber: (Penulis, 2021)

Gambar 6: Tampilan menu pada halaman "Data Anda"

\section{Halaman Analisis Data}

Sebelum diarahkan pada halaman Analisis Data pengguna akan memilih opsi untuk memasukkan data dengan input manual atau dengan import dari file CSV. Jika pengguna menggunakan opsi import dari file CSV maka bisa langsung diproses tanpa perlu memasukkan data satu per satu secara manual, dan jika pengguna menggunakan opsi input secara manual maka ada 2 step pengisian data yang harus dilakukan oleh pengguna.

Berikut diberikan contoh kasus pada implementasi aplikasi ini menggunakan opsi memasukkan data secara manual. Data yang digunakan adalah data dokumentatif dari Machali (2015). Data tersebut menceritakan sebuah studi kasus yang kemudian datanya diolah menggunakan uji-t dengan taraf alpha 0.05. Tidak ada ketentuan baku yang mengatur kapan penelitian menggunakan nilai alpha 0.05 atau nilai lainnya, misalnya 0.01. Nilai alpha 0.05 biasa digunakan oleh peneliti untuk penelitian yang memiliki akurasi bagus tapi tidak terlalu ketat dan biasa digunakan untuk data yang dipakai dalam hasil pengamatan di lapangan. Oleh karena itu taraf 0.05 cocok untuk digunakan pada contoh kasus ini. Data pada contoh kasus ini akan digunakan sebagai bahan pengujian aplikasi untuk mengetahui proses perhitungan yang dilakukan dan dihasilkan oleh aplikasi. Adapun contoh kasusnya seperti yang terdapat dalam Machali (2015) adalah seperti berikut.

Disebutkan terdapat dua ramuan kimia yaitu RDX dan DLL yang akan dijadikan sebagai campuran bahan bakar. Untuk itu perlu diuji efisiensi dari kedua ramuan tersebut terhadap pemakaian bahan bakar kendaraan. Sampel pengujian menggunakan 20 mobil yang terbagi menjadi dua kelompok, masing-masing 10 mobil. Diasumsikan bahwa 20 mobil tersebut memiliki karakteristik yang homogen. Tiap mobil diberi 1 liter bahan bakar dengan campuran 1 macam ramuan. Kelompok pertama diberikan ramuan RDX dan kelompok lainnya ramuan DLL. Penentuan 
efisiensi ramuan didasarkan atas jarak tempuh mobil dengan menghabiskan 1 liter bahan bakar yang telah dicampur ramuan. Data jarak tempuh tiap mobil yang diperoleh disajikan pada Tabel 1.

Tabel 1. Data Jarak Tempuh Mobil pada Contoh Kasus

\begin{tabular}{|c|c|c|}
\hline No. & RDX & DLL \\
\hline 1. & $5.21 \mathrm{Km}$ & $5.6 \mathrm{Km}$ \\
\hline 2. & $5.31 \mathrm{Km}$ & $5.21 \mathrm{Km}$ \\
\hline 3. & $5.32 \mathrm{Km}$ & $5.43 \mathrm{Km}$ \\
\hline 4. & $5.12 \mathrm{Km}$ & $5.34 \mathrm{Km}$ \\
\hline 5. & $5.16 \mathrm{Km}$ & $5.41 \mathrm{Km}$ \\
\hline 6. & $5.4 \mathrm{Km}$ & $5.26 \mathrm{Km}$ \\
\hline 7. & $5.29 \mathrm{Km}$ & $5.24 \mathrm{Km}$ \\
\hline 8. & $5.2 \mathrm{Km}$ & $5.42 \mathrm{Km}$ \\
\hline 9. & $5.14 \mathrm{Km}$ & $5.31 \mathrm{Km}$ \\
\hline 10. & $5.23 \mathrm{Km}$ & $5.15 \mathrm{Km}$ \\
\hline
\end{tabular}

Sumber: (Penulis, 2021)

Kasus ini menggunakan rumusan hipotesis seperti berikut:

$\mathrm{H}_{0}$ : Tidak ada perbedaan efisiensi antara bahan bakar RDX dan DLL

$\mathrm{H}_{1}$ : Ada perbedaan efisiensi antara bahan bakar RDX dan DLL

Berdasarkan data pada Tabel 1, yang harus dilakukan pengguna pada step pertama adalah mengisi form (halaman) berupa Nama Obyek, Deskripsi, Nama variabel sampel 1, Nama variabel sampel 2, Jumlah data variabel sampel 1 , Jumlah data variabel sampel 2, Hipotesis 0, Hipotesis 1, dan Alpha. Tampilan halaman Analisis Data pada step pertama ditunjukkan pada Gambar 7.

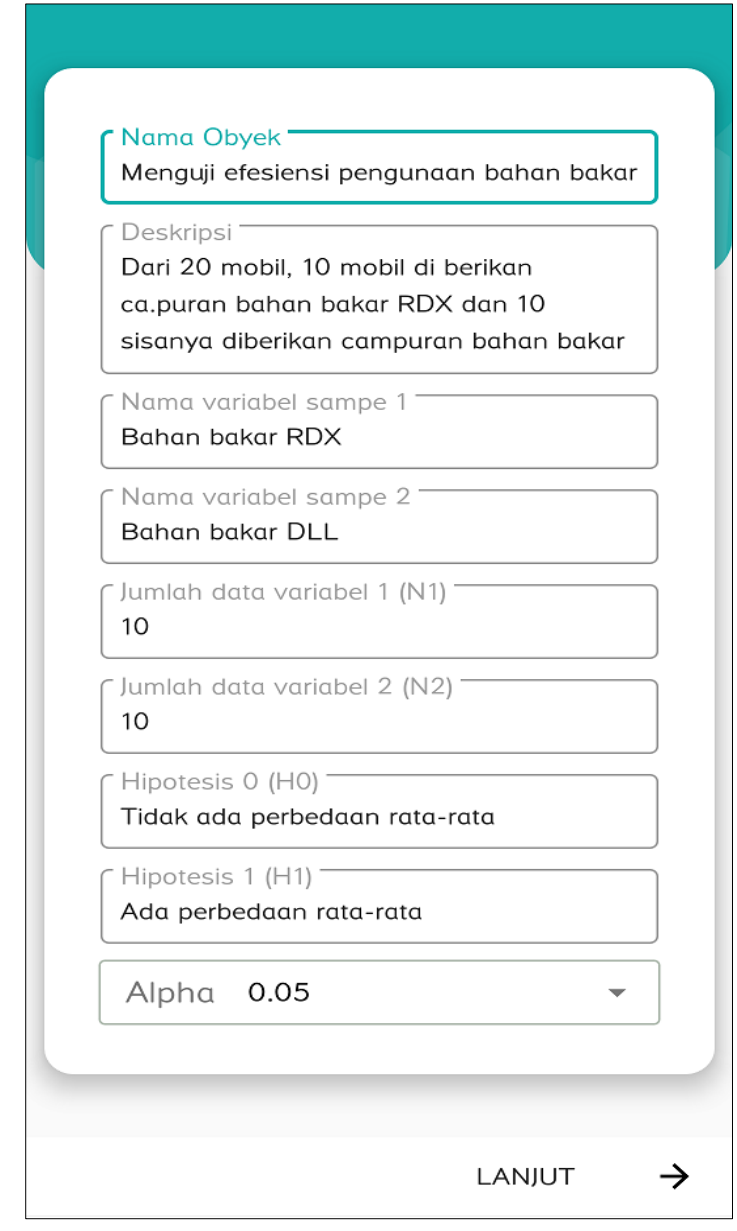

Sumber: (Penulis, 2021)

Gambar 7: Tampilan halaman Analisis Data step 1

Pada step ke-dua pengguna mengisi data sampel 1 dan sampel 2. Jumlah data pada sampel 1 dan sampel 2 menyesuaikan dengan jumlah yang telah dimasukkan pada step pertama. Halaman Analisis Data pada step ke-dua diperlihatkan pada Gambar 8. 


\begin{tabular}{|c|c|}
\hline Bahan bakar RDX & Bahan bakar DLL \\
\hline 5.21 & 5.6 \\
\hline 5.31 & 5.21 \\
\hline 5.32 & 5.43 \\
\hline 5.12 & 5.34 \\
\hline 5.16 & 5.41 \\
\hline 5.4 & 5.26 \\
\hline 5.29 & 5.24 \\
\hline 5.2 & 5.42 \\
\hline 5.14 & 5.31 \\
\hline 5.23 & 5.15 \\
\hline KEMBALI & SELESAI \\
\hline
\end{tabular}

Sumber: (Penulis, 2021)

Gambar 8: Tampilan halaman Analisis Data step 2

\section{Halaman Hasil Analisis Data}

Setelah pengguna memasukkan data pada halaman Analisis Data maka akan diarahkan ke halaman Hasil Analisis Data. Halaman ini ditampilkan kesimpulan dan nilai-nilai hasil perhitungan yang diproses dari aplikasi. Tampilan halaman Hasil Analisis Data ditunjukkan pada Gambar 9.

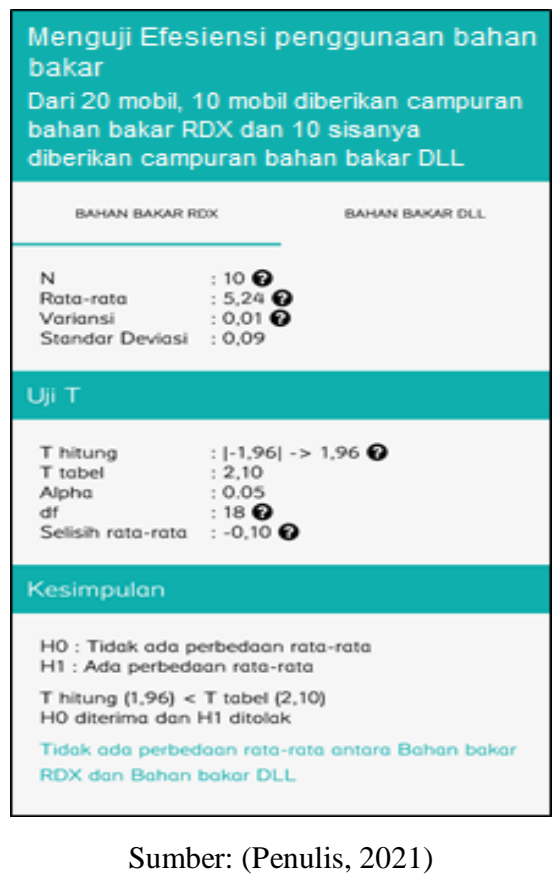

Gambar 9: Tampilan Hasil Analisis Data
Pada halaman Hasil Analisis Data terdapat tombol $\mathbf{O}$ yang bisa digunakan untuk melihat proses perhitungan manual. Hasil perhitungan manual ditampilkan berupa popup dialog sebagaimana terlihat pada Gambar 10.

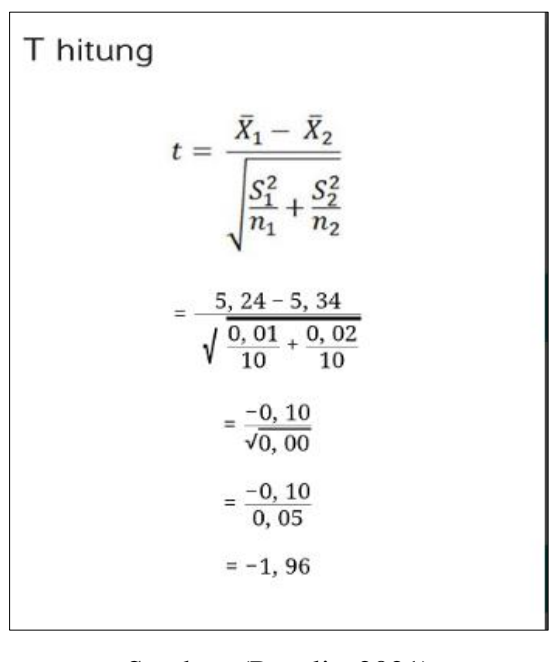

Gambar 10: Tampilan popup dialog proses perhitungan manual

\section{Pengujian Aplikasi}

Pengujian aplikasi dilakukan untuk mengetahui perhitungan yang diproses oleh aplikasi sudah benar atau salah. Pengujian dilakukan dengan cara membandingkan antara proses perhitungan secara manual, dengan aplikasi SPSS, dan dengan aplikasi yang telah dikembangkan. Data yang digunakan adalah data pada contoh kasus seperti yang telah disampaikan sebelumnya.

\section{Perhitungan Manual}

Pada proses perhitungan manual ini, dihitung rata-rata, variansi dan $T_{\text {hitung }}$ pada dua variabel sampel. Kemudian dari hasil $T_{\text {hitung }}$ dibandingkan dengan nilai $T_{\text {tabel }}$ untuk menentukan kesimpulan.

- Bahan bakar RDX

Rata-rata bahan bakar RDX (persamaan 1) (Siregar, 2017).

$$
\begin{aligned}
& \overline{\mathrm{x}}_{1}=\frac{\sum_{i=1}^{n} X i}{n} \\
& =\frac{5.21+5.31+\ldots \ldots \ldots+5.23}{10}
\end{aligned}
$$




$$
\begin{aligned}
& =\frac{52.38}{10} \\
& =5.238
\end{aligned}
$$

Variansi bahan bakar RDX (persamaan 2) (Siregar, 2017)

$$
\begin{aligned}
S_{1}^{2} & =\frac{\sum_{i=1}^{n}\left(X_{i}-\overline{\mathrm{x}}_{1}\right)}{n-1} \\
= & \frac{(5.21-5.24)^{2}+\ldots+(5.23-5.24)^{2}}{10-1} \\
= & \frac{0.07276}{9} \\
= & 0.008
\end{aligned}
$$

- Bahan bakar DLL

Rata-rata bahan bakar DLL (menggunakan persamaan 1 untuk variabel ke-2)

$$
\begin{aligned}
\overline{\mathrm{x}}_{2} & =\frac{\sum_{i=1}^{n} X i}{n} \\
& =\frac{5.6+5.21+5.43+\ldots \ldots+5.15}{10} \\
& =\frac{53.37}{10} \\
& =5.337
\end{aligned}
$$

Variansi bahan bakar DLL (menggunakan persamaan 2 untuk variabel ke-2)

$$
\begin{aligned}
S_{1}^{2} & =\frac{\sum_{i=1}^{n}\left(X_{i}-\overline{\mathrm{x}}_{1}\right)}{n-1} \\
= & \frac{(5.6-5.34)^{2}+\ldots \ldots+(5.15-5.34)^{2}}{10-1} \\
& =\frac{0.1572}{9} \\
& =0.0175
\end{aligned}
$$

- $T_{\text {hitung }}$

Setelah didapatkan hasil dari rata-rata dan variansi antara bahan bakar RDX dan bahan bakar DLL, selanjutnya adalah perhitungan dengan rumus $T_{\text {hitung }}$ menggunakan persamaan 3 (Siregar, 2017).

$$
\begin{aligned}
t & =\frac{\bar{x}_{1}-\bar{x}_{2}}{\sqrt{\frac{s_{1}^{2}}{n_{1}}+\frac{s_{2}^{2}}{n_{2}}}} \\
& =\frac{5.24-5.34}{\sqrt{\frac{0.008}{10}+\frac{0.0175}{10}}} \\
& =\frac{-0.10}{\sqrt{0.00} 2}
\end{aligned}
$$

- $T_{\text {tabel }}$

$$
=-1.96
$$

Nilai $T_{\text {tabel }}$ diperoleh dari tabel distribusi-t dengan mencocokkan harga derajat bebas atau degree of freedom (df) dan Alpha menggunakan persamaan 4 .

$$
\begin{aligned}
d f= & n 1+n 2-2 \\
& =10+10-2=18
\end{aligned}
$$

\begin{tabular}{|c|c|c|}
\hline & $\otimes$ nilai & @a bahan_bakar \\
\hline 1 & 5.21 & RDX \\
\hline 2 & 5.31 & RDX \\
\hline 3 & 5.32 & RDX \\
\hline 4 & 5.12 & RDX \\
\hline 5 & 5.16 & RDX \\
\hline 6 & 5.40 & RDX \\
\hline 7 & 5.29 & RDX \\
\hline 8 & 5.20 & RDX \\
\hline 9 & 5.14 & RDX \\
\hline 10 & 5.23 & RDX \\
\hline 11 & 5.60 & DLL \\
\hline 12 & 5.21 & DLL \\
\hline 13 & 5.43 & DLL \\
\hline 14 & 5.34 & DLL \\
\hline 15 & 5.41 & DLL \\
\hline 16 & 5.26 & DLL \\
\hline 17 & 5.24 & DLL \\
\hline 18 & 5.42 & DLL \\
\hline 19 & 5.31 & DLL \\
\hline 20 & 5.15 & DLL \\
\hline
\end{tabular}

Dengan menggunakan nilai Alpha $=0.05$, didapatkan harga $T_{\text {tabel }}$ sebesar 2.1009

- Kesimpulan

Karena $T_{\text {hitung }}(|-1.96|)<T_{\text {tabel }}$ (2.1009), dengan demikian terjadi penerimaan $H_{0}$ dan penolakan $H_{1}$.

Kesimpulannya adalah tidak ada perbedaan efisiensi antara bahan bakar yang mengandung campuran RDX dan campuran DLL.

\section{Menggunakan aplikasi SPSS}

Pengujian menggunakan aplikasi SPSS dilakukan dengan cara memasukkan data nilai bahan bakar RDX dan bahan bakar DLL pada SPSS. Visualisasi data contoh kasus ini ditunjukkan pada Gambar 11.

Sumber: (Penulis, 2021)

Gambar 11: Data bahan bakar RDX dan DLL pada SPSS 
Hasil perhitungan pada Group Statistics didapatkan rata-rata bahan bakar RDX dan DLL adalah 5.238 dan 5.337, seperti pada Tabel 2.

Tabel 2. Hasil perhitungan SPSS pada Group Statistics

\begin{tabular}{|l|l|c|c|c|c|}
\hline & $\begin{array}{c}\text { Bahan } \\
\text { bakar }\end{array}$ & N & Mean & $\begin{array}{c}\text { Std. } \\
\text { Deviation }\end{array}$ & $\begin{array}{c}\text { Std. } \\
\text { Error } \\
\text { Mean }\end{array}$ \\
\hline nilai & RDX & 10 & 5.2380 & .08991 & .02843 \\
\hline & DLL & 10 & 5.3370 & .13217 & .04179 \\
\hline
\end{tabular}

Sumber: (Penulis, 2021)

Hasil dari perhitungan pada Independent Sample Test didapatkan nilai $T_{\text {hitung }}-1.958$ dengan derajat bebas 18, seperti dipresentasikan di Tabel 3.

Tabel 3. Hasil perhitungan SPSS uji-t 2 sampel independent

\begin{tabular}{|c|l|c|c|c|}
\hline \multicolumn{2}{|c|}{} & \multicolumn{2}{|c|}{$\begin{array}{c}\text { Levene's Test for } \\
\text { Equality of } \\
\text { Variances }\end{array}$} & $\begin{array}{c}\text { t-test for } \\
\text { Equality } \\
\text { of } \\
\text { Means }\end{array}$ \\
\cline { 3 - 5 } & \multicolumn{2}{|c|}{ F } & Sig. & t \\
\hline \multirow{2}{*}{ nilai } & $\begin{array}{l}\text { Equal variances } \\
\text { assumed }\end{array}$ & 1.116 & .305 & -1.958 \\
\cline { 2 - 5 } & $\begin{array}{l}\text { Equal variances } \\
\text { not assumed }\end{array}$ & & & -1.958 \\
\hline
\end{tabular}

Sumber: (Penulis, 2021)

Dari hasil perhitungan SPSS didapatkan kesimpulan bahwa bahan bakar RDX dan bahan bakar DLL tidak ada perbedaan yang signifikan dengan tarap alpha 5\%, perbedaan rata-rata bahan bakar RDX (5.238) dan DLL (5.337) hanya selisih 0.099 yang relative kecil sehingga dianggap perbedaan ini kurang signifikan.

\section{Menggunakan aplikasi yang dikembangkan}

Sebagaimana yang telah disampaikan sebelumnya bahwa halaman untuk memasukkan data ada pada menu analisis data. Tahap pertama yang harus dilakukan pengguna adalah memasukkan data dari obyek yang diteliti. Halaman entri data ini ditunjukkan pada Gambar 12.

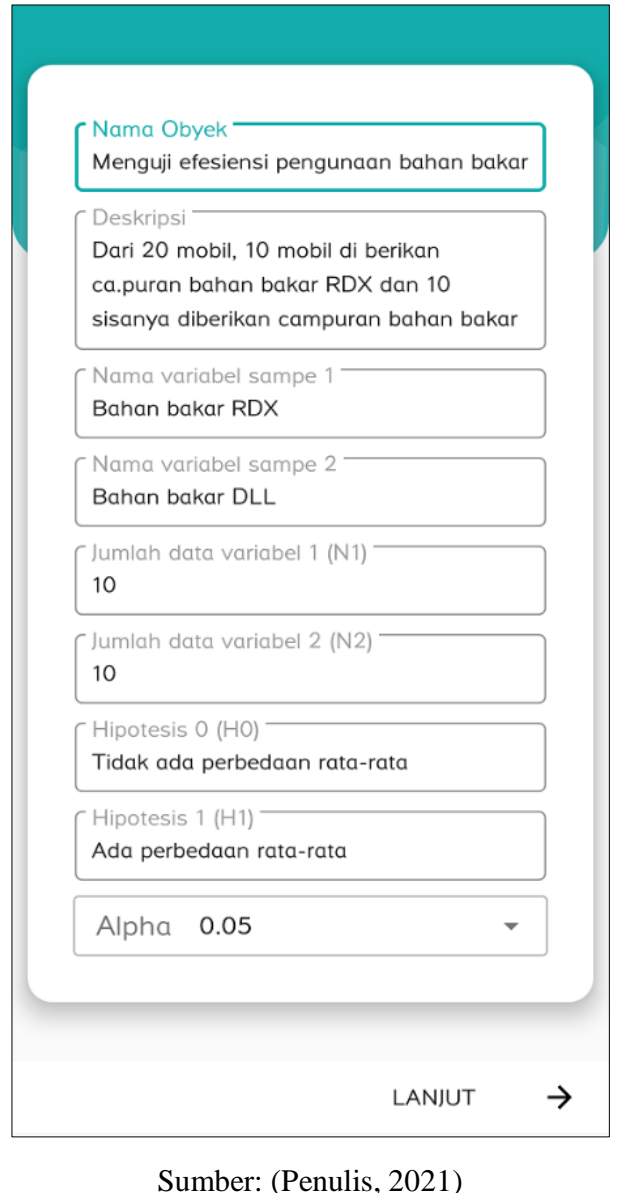

Gambar 12: Halaman entri data obyek yang diteliti

Tahapan ke-2 adalah mengisi nilai setiap variabel yang ada. Jumlah data pada variabel sampel menyesuaikan pada jumlah data variabel yang sudah dimasukkan pada tahap pertama yaitu $\mathrm{n} 1$ dan $\mathrm{n} 2$ masing-masing 10 data (Gambar 13).

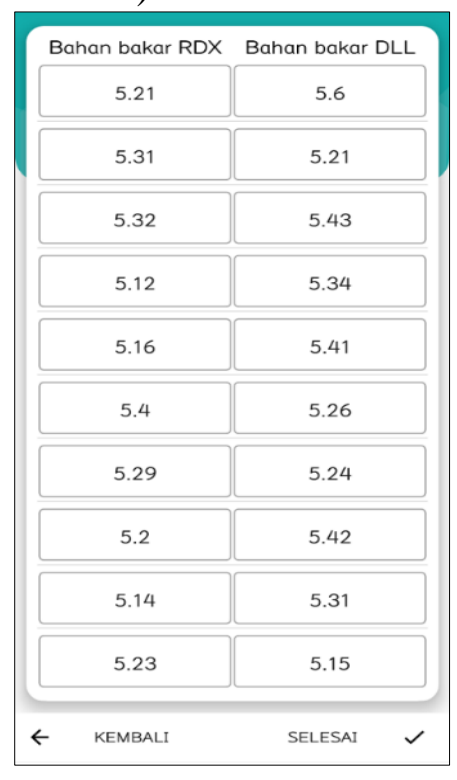

Sumber: (Penulis, 2021)

Gambar 13. Halaman entri data nilai variabel sampel 
Setelah proses memasukkan data selesai maka diperoleh hasil perhitungan menggunakan aplikasi. Hasil yang didapatkan adalah bahwa $T_{\text {hitung }}$ lebih kecil daripada $T_{\text {tabel }}$. Hal ini memperlihatkan tidak adanya perbedaan efisiensi antara ramuan RDX dengan DLL. Hasil perhitungan ini ditunjukkan pada Gambar 14.

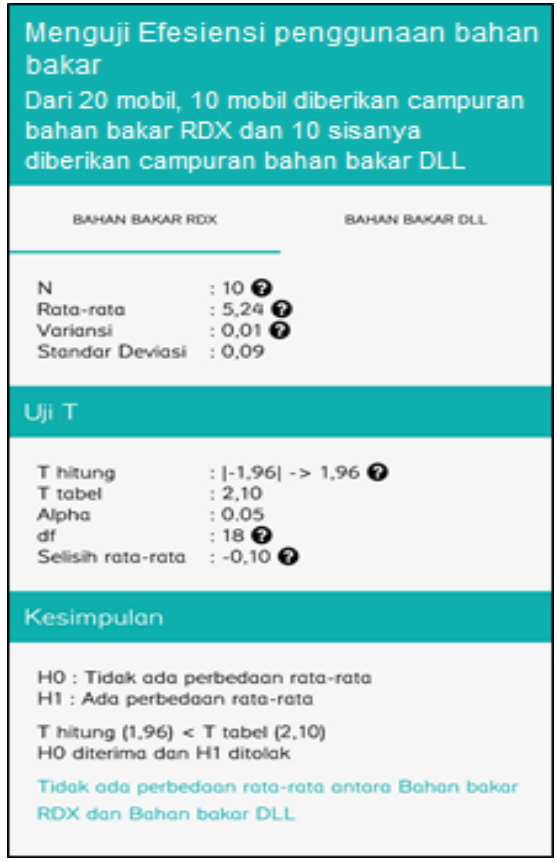

Sumber: (Penulis, 2021)

Gambar 14: Hasil perhitungan dengan aplikasi yang dikembangkan

Berdasarkan hasil pengujian yang telah disampaikan, proses perhitungan baik itu secara manual, dengan menggunakan SPSS dan menggunakan aplikasi yang dikembangkan memperoleh hasil perhitungan yang tidak berbeda atau tidak ada perbedaan dalam hasil perhitungan. Dari 3 proses perhitungan dalam pengujian tersebut, dapat disimpulkan bahwa aplikasi yang dikembangkan yaitu aplikasi statistika untuk analisis uji-t 2 sampel independen berbasis android ini dapat dijadikan alat bantu atau tool yang bisa digunakan oleh pengguna untuk menganalisis data.

\section{KESIMPULAN}

Telah dikembangkan sebuah aplikasi untuk analisis data menggunakan uji-t dua sampel independen berbasis android. Hasil perhitungan yang diperoleh dari aplikasi ini memberikan sebuah kesimpulan yang dapat diinterpretasikan berupa kalimat dan dapat menampilkan proses perhitungan secara manual sehingga memudahkan pengguna dalam menganalisis data. Berdasarkan kemampuannya dalam memberikan deskripsi hasil analisis data sesuai dengan hipotesis yang digunakan, pengguna tidak perlu lagi menginterpretasikan keluaran hasil analisis untuk menentukan apakah Ho diterima atau ditolak. Aplikasi ini dapat dikembangkan menjadi program yang lebih kompleks dengan menambahkan beberapa pengujian parametrik.

\section{DAFTAR PUSTAKA}

Ary, M. (2016). Pengklasifikasian Karakteristik Mahasiswa Baru Dalam Memilih Program Studi Menggunakan Analisis Cluster. Jurnal Informatika, 2(1), 181-188. https://doi.org/10.31311/ji.v2i1.58

eMakerter. (2019). Pengguna Smartphone di Indonesia 2016-2019. Https://Databoks.Katadata.Co.Id/Dat apublish/2016/08/08/PenggunaSmartphone-Di-Indonesia-20162019.

Gauthier, T. D., \& Mark E, H. (2017). Introduction to Environmental Forensics. Academic Press.

Gerald, B. (2018). A Brief Review of Independent, Dependent and One Sample t-test. International Journal of Applied Mathematics and Theoretical Physics, 4(2), 50. https://doi.org/10.11648/j.ijamtp.201 80402.13

Machali, I. (2015). Statistik Itu Mudah: Menggunakan SPSS sebagai Alat Bantu Statistik. In MPI FITK UIN Sunan Kalijaga Yogyakarta. Ladang Kata. 
Mustafidah, H., \& Suwarsito, S. (2020). Dasar-dasar Metodologi Penelitian. UMP Press.

Pandey, R. (2015). Commonly used t-tests in medical research. Journal of the Practice of Cardiovascular Sciences, 1(2), 185. https://doi.org/10.4103/23955414.166321

Rosa, A. ., \& Shalahuddin, M. (2014). Rekayasa Perangkat Lunak Terstruktur dan Berorientasi Objek. Informatika.

Sagoro, E. M. (2016). Keefektifan Pembelajaran Kooperatif Berbasis Gamifikasi Akuntansi Pada Mahasiswa Non-Akuntansi. Jurnal Pendidikan Akuntansi Indonesia, 14(2), 63-79.
Siregar, S. (2017). Statistik Parametrik untuk Penelitian Kuantitatif (Fandy Hutari (ed.); 5th ed.). PT Bumi Aksara.

Taniredja, T., \& Mustafidah, H. (2011). Penelitian Kuantitatif (Sebuah Pengantar). ALFABETA.

Wanakacha, C. K., Aloka, P. J. O., \& Nyaswa, P. (2018). Gender differences in motivation and teacher performance in core functions in Kenyan secondary schools. Academic Journal of Interdisciplinary Studies, 7(1), 89-95.

Yusop, H., Yeng, F. F., Jumadi, A., Mahadi, S., Ali, M. N., \& Johari, N. (2015). The effectiveness of excellence camp: A study on paired sample. Procedia Economics and Finance, 31(15), 453461. 